\title{
Iran and Turkey: from regional competition to trading partnership
}

\author{
Roza Habibi ${ }^{1, *}$, Akbar Mahdizadeh ${ }^{2}$ \\ ${ }^{1}$ International Relations, Tasouj Branch, Islamic Azad University, Tasouj, Iran \\ ${ }^{2}$ Department of International Relations, Tabriz Branch, Islamic Azad University, Tabriz, Iran \\ *E-mail address: rozahabibi8521@yahoo.com
}

\begin{abstract}
The profound and accelerated developments of the region have paved the way for the role play of the regional actors. In this regard, the role of Iran and Turkey as two regional powers is clear and undeniable. Iran and Turkey are two major players of the region whose roles and limit of effectiveness differ and are sometimes complementary. The closeness of these two players creates a strong political, security and economic bloc in the Middle East. Upon emphasizing the ancient history and heritage of two great empires, the collaboration of Iran and Turkey is the best chance to compensate the past tensions and to obtain trade cooperation, stability and peace. As a result, the present research deals with the relations of the two countries.
\end{abstract}

Keywords: Regional competitors; Trading partners; Cooperation; Middle East

\section{INTRODUCTION}

In recent years, we have observed Turkey has been well aware of the importance and role of soft power in its political relations and affairs in the global developments and the Islamic world. Whenever it has felt its soft power can't cope with problem s, Turkey has combined its soft and hard power based on theory by Joseph Nye, has achieved an intelligent power, has managed to apply it for most case, and particularly at times it has faced with problems, like the recent Syrian developments. The strategic and geographic situation of Turkey as a linking bridge of the west with the Orient has enhanced the position of this country, so that it has introduced itself as a Muslim model country in the region. Turkey adopting an ancient history compared to other countries has found a superior place for itself in the region. However, this is not the end of the story, because Iran neighbors Turkey. Iran and Turkey, due to their geographic and geopolitical locations and their long ancient civilizations have created an attractive market in the region. Furthermore, the two countries, because of linguistic, religious, cultural and historical rarity are already regarded as regional competitors. However, a range of domestic developments in Iran and Turkey as well as international and regional developments have resulted in the promotion of bilateral relations is o easy task. Neighbors have a special position, because the qualities of establishing relations with them are found to be deeply effective in fulfilling national security, political and economic developments. Both Iran and Turkey are in special positions regionally and 
strategically where this position is at first indebted to the very geography in which they are situated. A look at the history of the two countries shows most developments of the two countries are mutually effective in keeping with one another and consequences do exit for the two countries. Clear instances could be Ata Turk and Reza Khan in Iran as well as coup by Mosadegh and Manders. However, the range of relations between Iran and Turkey has always been extensive. For example, the recent Turkey developments On December $16^{\text {th }}$ could be cited where traces of Iran's sanctions are seen. Unilateral sanctions imposed on Iran by the west, became a chance for the two counties to expand their own relations. Sanctions provide a new opportunity for the Turkish business firms to eliminate the negative consequences of the sanctions and bureaucracy seen as main obstacles to the bilateral relations. Under such circumstances where sanctions and pressure were imposed on Iran, there stood, political policies influenced by new elite thoughts and approaches who found the chance to couch in their beliefs. This in turn, transformed domestic and state policy - making. With regards to relations between Iran and Turkey, the cooperation and economic collaboration was just a response to global and regional necessities that would threaten the two countries.

The very response was a role play in the economic ties. Ground breaking historic, geographic, cultural, linguistic and religious factors resulted in an overlay of many benefits. Convergent issues that resulted in the ever increasing closeness of the two countries like the issue of Iraqi Kurdistan, opposition to armed Kurdish parties, stance against Israel, regional attitude to Islamic movements of Hamas and Hizbollah, regional collaboration (Islamic conference, Eco, D8), economic trade and discussions and enemy issues were matters influenced by divergent issues as including stance towards the U.S., NATO, mid Asia, and Caucasus. Although Iran is faced with two challenges of economic crisis and sanctions (structural weakness), it enjoys unique opportunities, like utilizing substantial monetary and portfolio resources, huge oil and gas reserves, special economic station in the region, access to free waters, educated young population, domestic markets and political stability. To the contrary, Turkey has limited oil and gas resources, but it has filled this shortfall with competition service population.

The Turkish tourism industry attracts 20 million people annually. Today, because of the presence of constriction companies, Turkey receives varied orders and demands from the Middle East and Africa. More importantly, the famous Turkish universities, which is on the rise attracts many students from Iran and totally all off this have made Turkey role play as a model and act as an effective international actor within the global community. Understanding the issue why the states cooperate is not primarily a complicate issue, rather it is the mutual profit based - relationship that persuades them to establish such relations (Shoori, 2008). Energy strategy is part $\mathrm{f}$ the national security, and development strategy of the states. Today, economic growth an; political power of the states are closely interrelated with then energy security.

Thus, states in the world, apply all their tools from diplomacy to information to economy and military force so to satisfy the energy security (Zibakalam \& Goodarzi, 2013). Explaining and understanding the foreign policy developments, approaches and proclamation of states' positions undoubtedly hinge upon principles and performance basics of the decision making entities. In other words, understanding the philosophical foundation that is necessarily affected by domestic facilities and international confinements will culminate in 
adopting approaches whose deconstruction and explanation could embody behavioral patterns at different levels - National, regional and international (Asgarkhani \& Arghavanipirsalami, 2011).

\section{NATIONAL POWER}

Various opinions are expressed with regards to the national power as conceptual elements off the national security and thinkers have rolled theories on classification of it. For example, prior to the Second World War a German scholar categorized the elements f power to three branches:

A. Geographic and political factors: Like geographic location, land expansiveness, population level, skill in putting up political outfits, cultural depth, the quality of borders and communication with other countries.

B. Economic factors: Like rich energy resources, trading potentiality, transportation system, and investment, monetary and banking sources.

C. Mental factors: Like the talent of innovation and creativity, perseverance, resilience, forbearance and tolerance of problems, general morale of the people (Khashee, \& Morademamzade Jafar, 2011).

The important point is that Turkey has already been among the priorities of the Islamic republic of Iran's foreign policy in recent years. Turkey should based on the Davood Uglo's doctrine revive the policy of zero tension with neighbors. The Turkish foreign policy is founded on the three principles.

First, an active regional presence officiated by Ankara by adopting soft power in its foreign policies and in settling surrounding crises like the Armenia example solved as a cultural issue. Second, Islamism, this principle is introduced in two dimensions of Turkish foreign policy, a) as a democratic state model and as a successful model in the Islamic world and $b$ ) as a Muslim country. Third, the issue of Turkish neutrality and representation of Turkey as an intermediary for solving regional issues like efforts to sole the Iranian nuclear crisis. However, the Turkish foreign policy focuses greatly on the role of cultural and economic relations.

Turkey has always called for expansion of ties with neighboring countries. Because, Turkey has long attempted to become one of the top ten economies of the world, it has paid special attention to Iran as an export and consumption market. With changes emerging in the Turkish foreign policy in recent years and Islamists coming to power, as well as stability and security brought up by the justice and development party led by Erdoghan recently, caused to change economic growth, inflation reduction, tourism industry, and regional policies that strengthen peace and stability in the region.

Turkey, in recent years went through domestic tensions that affected the Turkish foreign policy. In analysts' views, the proceedings of the justice and development party have directed at undemocratic trends, such as bellicose policies and distortion of the zero tension policy with neighbors, hence, this could vanish the accomplishments by the justice and development party (Davoodgloo, 2010).

The issue of supporting the people of Palestine and their rights is a shared point. Another shared point is the issue of Kurds, which has caused the elation to strengthen in recent year. Energy resources also matter in ten relations of the two countries. The Turks' 
urgent need to energy resources an $d$ the fact that Iran possesses huge oil and gas resources as well as the Iran's need to transfer energy to Europe via the Turkish soil was topic not distorted by sanctions imposed on Iran.

To analysts, Turkey grabbed this opportunity to promote its national interest. Increased energy imports along with raised oil and gas prices have extended Turkey's imports from Iran .It is noteworthy, Turks' exports to Iran has seen a considerable growth in the past years and with respect to capital investment, it should be noted that investment is an important part of economic trade between the two countries. Capital investment has increased as states have placed exemptions. Turkey has resisted sanctions against Iran imposed by the west. Economic benefits in the relations of the two countries are so huge that the two strive to minimize their political difference, by ignoring the tensions about Caucasus, mid Asia, NATO and Syria.

They also attempt to nicely manage these tensions. A salient example of the management, cooperation in the 4 centuries of comfort, peace and security in the borders of the two countries. Generally, it can be said that the two countries in the area of the foreign policy from regional have changed course from regional competition to trading partners. However, the question is whether Turkey's joining the EU will challenge this direction or not. For Turkey, EU membership and westernization as a whole has been one of the most important concerns of this country. One can refer to efforts by Ata Turk and reformists politicians to join the NATO and European institutions. The European Union has a long history.

The stance on joining the EU will result numerous developments and advantages in the bargaining power, increasing the foreign investment, reducing the unemployment rate, improving welfare, accelerating trends for Turkey. However, upon EU membership, Turkey will be placed in the safety context and in most cases, it'll adjust its economic and foreign policies based on the EU laws against Iran. If EU insists on imposing economic sanctions on Iran, Turkey will not be virtually able to adopt an independent policy from Europe and the Union's laws in the form of custom union will prevent Turkey to favorably export and import goods.

\section{IRAN'S EU MEMBERSHIP}

Turkey's membership in the EU will involve opportunities and threats for Iran. Huge oil and gas resources and the importance of energy for the west and Turkey will result in the free export to the Europe, thus enhancing the importance of Iran for the EU. In accordance with the geostrategic importance of Iran, in case Turkey becomes a member of the EU, Iran will be a neighbor to the EU and it'll treat Iran in ten frameworks of policies based on neighborhood with Iran. This could follow certain advantages for Iran.

This neighborhood will involve its specific consequences for Iran. For example, one can refer to ever increasing expansion of democracy. Iran, could using the cooperation alleviate security threats like narcotics, good smuggling and human trafficking. In terms of exports, Iran can open a special account on a 500 million market. Scientific, communication and technological cooperation are among the advantages of this neighborhood. If Iran can't apply this type of cooperation, there will be many threats and challenges for Iran. 
The main point with regards to the relations between Iran and Turkey that has strengthened the relations is the lack of border conflicts that this could be turning point in the relations of the two countries. Turkey's move to the EU could minimize the tension making issues in the area of central Asia, Caucasus and Kurds and the two countries' supports towards issues will be much lower (Abdoli, 2011).

Of main strategies that Iran has to consider in its economic, trade and political relations with Turkey are:

- Attempts to create a model of bilateral economic cooperation for expansion of economic ties, first in the form of energy and then its development.

- Attempts to implement the plan of connecting Iran to Europe via Turkey to reduce the problems of the Iranian exports.

- Reducing the trading risk of Iranian good exports to the European countries and increasing the volume of transition to this country.

- Investing in Turkey dispatching Iranian technical experts to this country.

\section{CONCLUSIONS}

The present condition of the affected political and economic developments in the country new atmosphere different from the former policy is the use of new opportunities and meet economic challenges can be approached Iran and Turkey as neighbors with close linguistic and cultural, historical and religious say. Specific location and boundaries of strategic energy reserves sharing all the world needs peace and be of mutual cooperation between the two countries is positive. But it is still unknown and obscure aspects of bilateral relations, which are all near everyone away. Turkey is one of Iran major economic partners in the world and that is a pillar of regional security and stability and has a common border. So that the negative effects of conflicting and divergent elements has the least possible.

\section{References}

[1] Abdoli S. (2011). Effects of Turkey's membership in the EU, http://www.policy.blogfa.com/post/4

[2] Asgarkhani A., Arghavanipirsalami F. (2011). Policy of constructive interaction and the necessity of Iranian economic development affairs and Africa, Quarterly of foreign reactions, (3)2: 133-159.

[3] Azizi H. (2013). Relations between Iran and Turkey under the presidency of Rouhani, Research center for the Mideast strategic studies, http://fa.merc.ir/article/Middle East/Turky.aspx

[4] Davoodugloo A. (2010). Strategic depth: Turkey's location and its role in the international arena, Turkey: Scientific Darolarabia Publications.

[5] Dehnavi N. (2007). Documents about the relation between Iran and Turkey, Tehran: Center for the foreign ministry documents. 
[6] Khashee V., Morademamzade Jafar M. (2011). A policy making introduction to the efficiency of soft power in the international arena, Soft power studies, (1)3: 51-76.

[7] Shoori M. (2008). Iran and Russia: From the balance of power to the issue of identity, International quarterly of foreign affairs, (1)2: 219-242.

[8] Zibakalam S., Goodarzi M. (2013). Energy security and the policy of Tajikistan's open doors, Studies of the Central Eurasia, (6)12: 75-94. 